\title{
Sistem Pemidanaan Terhadap Pelaku Tindak Pidana Penyalahguna Narkotika
}

\author{
Dafit Supriyanto Daris Warsito*
}
Mahasiswa Program Magister (S2) Ilmu Hukum Fakultas Hukum UNISSULA Semarang, bekerja di Kejaksaan Negeri Blora, email dafits74@gmail.com

\begin{abstract}
ABSTRAK
Penyalahgunaan narkotika dikualifikasikan sebagai tindka pidana dalam Undang-undang Nomor 35 Tahun 2009 tentang Narkotika.Penerapan system pemidanaan terhadap pelaku tindak pidana penyalahguna nakotika mengedepankan pendekatan humanistic yang memperhatikan prinsip individualisasi pidana dalam penggunaan sanksi pidana sebagai salah satu sarana penanggulangan kejahatan.

Pada hahekatnya pelaku penyakahguna narkotika juga merupakan korban yang membutuhkan pertolongan medis. Penerapan tindakan berupa rehabilitasi medis dan social bertujuan untuk memperpaiki keadaan diri penyalahguna narkotika agar terbebas dari ketergantungan narkotika sehingga dapat kembali ke masyarakata secara wajar.

Kata kunci : penyalahguna narkotika, rehabilitasi medis dan social
\end{abstract}

\section{ABSTRACT}

Narcotics abuse is qualified as a criminal offense in Act No. 35 of 2009 about Narcotics. The implementation of punishment system against perpetrators of criminal acts of narcotic advocates a humanistic approach which takes into account the principle of criminal individualization in the use of criminal sanctions as one means of crime prevention.

Drug abuser perpetrators are also victims who need medical help. The implementation of the action in the form of medical and social rehabilitation aims to improve the self-condition of narcotics abusers in order to be free from narcotics dependence so that they can return to normal society.

Keywords: narcotics abusers, medical and social rehabilitation

\section{PENDAHULUAN}

Peredaran gelap narkotika menjadi ancaman yang sangat berbahaya bagi kelangsungan generasi muda. Generasi muda menjadi sasaran yang Peredaran gelap narkotika menyasar ke genenarsi muda yang secara psikologis masih labil sehingga mudah untuk dipengaruhi untuk menggunakan narkotika. Generasi muda sangat rawan menjadi sasaran trategis mafia perdaganagn narkotika ${ }^{1}$. Remaja merupakan golongan yang rentan terhadap penyalahgunaan narkotika karena kecenderungan mereka untuk ingin mencoba yang didorong dengan rasa penasaran.

Berdasarkan sejarah penggunaannya, narkotika hanya digunakan sebagai alat ritual keagamaan dan pengobatan, adapun jenis narkotika yang pada mulanya digunakan adalah candu atau lazim

\footnotetext{
${ }^{1}$ Herlina Martono dan Satya Joewana, Belajar Hidup Bertanggungjawab, Menangkal Narkotika dan Kekerasan, Balai Pustaka, Jakarta, 2008, hlm. 26.
} 
disebut madat atau opium². Namun seiring perkembangan jaman, narkotika justru disalahgunakan untuk hal-hal diluar pengobatan padahal dampak penggunaan narkotika sangat membahayakan. Penyalahgunaan narkotika adalah penggunaan narkotika yang bukan untuk tujuan pengobatan, tetapi agar dapat menikmati pengaruhnya, dalam jumlah berlebih, secara kurang lebih teratur, berlangsung cukup lama sehingga menyebabkan gangguan kesehatan secara fisik, gangguan kesehatan jiwa dan kehidupan sosialnya ${ }^{3}$. Bahkan penggunaan narkotika dalam jumlah berlebihan (overdosis) dapat menyebabkan kematian.

Narkotika dan obat-obatan terlarang seperti ganja, heroin dan sejenisnya, dalam Islam disebut dengan istlah mukhaddirat. Hukum mengkonsumsi benda-benda ini apapun bentuknya adalah haram. Tidak ada peselisihan antara ulama dalam hal ini, mereka menyepakati keharaman mukhaddirat ini. Para ulama mengqiyaskan hukum mukhaddirat pada hukum khamar. Menurut hadist yang dikemukakan oleh Umar bin Khatab RA "khamar adalah segala sesuatu yang menutup akal" (HR Bukhari Muslim) ${ }^{4}$.

Dunia intenasional pun menganggap peredaran gelap narkotika sebagai kejahatan luar biasa. Hal ini dibuktikan dengan diadakan Konvensi Tunggal Narkotika 1962 dan Konvensi Wina 1988. Konvensi Tunggal Narkotika menitikberatkan pada aspek pengaturan dan pengawasan sedangkan Konvensi Wina menitikberatkan pada aspek penegakan hukum ${ }^{5}$.

Upaya peningkatan di bidang pengobatan dan pelayanan kesehatan, ketersediaan narkotika diperlukan namun apabila disalahgunakan akan menimbulkan dampak yang berbahaya bagi penggunanya karena pengguna akan mengalami ketergantungan yang sangat merugikan sehingga harus dilakukan pengendalian dan pengawasan yang ketat dan seksama ${ }^{6}$. Oleh karena itu Indonesia menyediakan regulasi yang mengatur tentang peredaran narkotika, penggunaan narkotika untuk pengobatan dan pengembangan ilmu pengetahuan, larangan tanpa hak memperjualbelikan, menyimpan, menguasai, membawa dan menyalahgunakan naarkotika.

Awalnya Indonesia mengundangkan Undang-undang Nomor 8 Tahun 1976 yang merupakan pengesahan hasil Konvensi Tunggal Narkotika 1961 beserta protokol perubahannya. Berdasarkan Undang-undang Nomor 8 Tahun 1976, Indonesia mengesahkan Undang-undang Nomor 9 Tahun 1976 tentang Narkotika. Dalam perkembangannya undang-undang ini diperbaharui dengan Undangundang Nomor 22 Tahun 1997 tentang Narkotika. Dalam undang-undang ini diatur mengenai larangan penyalahgunaan narkotika bagi diri sendiri sebagaimana tercantum dalam Pasal 85 Undangundang Nomor 22 tahun 1997 sebagai berikut "barang siapa tanpa hak dan melawan hukum : a) menggunakan narkotika golongan I bagi diri sendiri dipidana dengan pidana penjara paling lama 4 (empat) tahun, b) menggunakan narkotika golongan II bagi diri sendiri, dipidana dengan pidana

\footnotetext{
${ }^{2}$ Kusno Adi, Diversi Sebagai Upaya Alternative Penaggulangan Tindak Pidana Narkotika Oleh Anak, UM Press, Malang, 2009, hlm. 3.

3 https://media.neliti.com//media/publications/169828-10-faktor-faktor -penyebab-penyalahgunaan-na.pdf diakses hari senin tanggal 6 Nopember 2017 jam 11.00 WIB.

${ }^{4}$ www.republika.co.id/berita/koran/dialog-jumat/15/05/08/no0x0828-narkotika-dalam-fikih-islam diakses pada hari Rabu tanggal 7 Nopember 2017 jam 10.00 WIB

${ }^{5}$ Kusno adi, Op.Cit. Hal. 4

${ }^{6}$ Ibid.
} 
penjara paling lama 2 (dua) tahun, c) menggunakan narkotika golongan III bagi diri sendiri, dipidana penjara paling lama 1 (satu) tahun" ${ }^{7}$. Apabila dicermati, stelsel pemidanaan dalam undang-undang ini hanya menggunakan stelsel pemidanaan tunggal yang artinya bahwa pidana yang dapat dijatuhkan terhadap pelaku penyalahgunaan narkotika hanya pidana penjara.

Dalam perkembangannya, banyak pelaku-pelaku penyalahgunaan narkotika bukanlah termasuk pengedar ataupun terlibat dalam sindikat peredaran gelap narkotika, sering kali motivasi mereka menggunakan narkotika hanya karena didorong rasa penasaran, mengikuti jejak teman-temannya, mencoba mencari eksistensi diri dalam pergaulan dengan cara yang salah. Orang-orang terutama generasi muda yang menggunakan narkotika hanya sebatas coba-coba kemudian sampai mengalami ketergantungan tentunya juga harus dianggap sebagai korban peredaran gelap narkotika. Bermula dari coba-coba padahal penggunaan narkotika tujuannya menimbulkan kenikmatan bagi pemakai, sehingga terjadi suatu ketergantungan psikologis ${ }^{8}$. Bahkan ketergantungan terhadap narkotika juga menjadi salah satu penyebab munculnya perilaku melanggar hukum. Tentunya terhadap kondisi seperti ini juga harus diperlakukan berbeda dengan orang-orang yang memang sengaja mengeruk keuntungan dari peredaran gelap narkotika.

Para penyalahguna narkotika, sangat dimungkinkan sudah mengalami kecanduan sehingga sulit untuk melepaskan diri dari jerat pemakaian narkotika tanpa mendapat bantuan dari ahli. Penerapan pidana penjara bagi penyalahguna khususnya pecandu narkotika dipandang sebagai tindakan yang kurang tepat karena pidana penjara hanya memberikan nestapa saja kepada pelaku tanpa menyembuhkan ketergantungannya dari narkotika. Selain itu, dengan dipenjaranya pecandu narkotika membuka peluang pecandu narkotika menjadi pengedar atau bahkan menjadi pelaku tindak pidana lainnya karena pidana penjara kondisi lembaga pemasyarakatan yang ada di Indonesia belum dapat maksimal dalam melakukan pembinaan terhadap warga binaannya

Penjatuhan pidana terhadap penyalahguna narkotika tentunya diharapkan tidak saja memberikan efek jera bagi pelakunya namun juga sebagai sarana penanggulangan kejahatan. Pendekatan humanistic juga harus diperhatikan dalam memberikan sanksi hukum kepada penyalahguna narkotika. Pendekatan yang berorientasi pada nilai humanistic inilah yang menghedaki diperhatikannya prinsip individualisasi pidana dalam penggunaan sanksi pidana sebagai salah satu sarana penanggulangan kejahatan ${ }^{9}$.

Saat ini, Undang-undang Nomor 22 Tahun 1997 dicabut dan digantikan dengan Undang-undang Nomor 35 Tahun 2009 tentang Narkotika. Hal ini mendorong penulis untuk mengetahui bagaimana sistem pemidanaan terhadap pelaku tindak pidana pennyalahguna narkotika menurut Undangundang Nomor 35 Tahun 2009 tentang Narkotika.

\footnotetext{
${ }^{7}$ Undang-undang Nomor 22 Tahun 1997 tentang Narkotika, Pasal 85

${ }^{8}$ Sukarmi, Psikologi Hukum, Unissula Press,Semarang, 2012, hlm. 47.

${ }^{9}$ Sri Endah Wahyuningsih, Prinsip-prinsip Individualisasi Pidana Dalam Hukum Pidana Islam dan Pembaharuan Hukum Pidana Indonesia, Badan Penerbit Universitas Diponegoro,Semarang,2013,hlm.82
} 


\section{PEMBAHASAN}

Sistem pidana identik dengan sistem penegakan hukum pidana atau system pemberian/penjatuhan/pelaksanaan pidana $^{10}$. Tempat dan kedudukan peradilan dalam Negara hukum dan masyarakat demokrasi, masih tetap diandalkan $:^{11}$

1. Sebagai "katup penekan" atau pressure valve atas segala pelanggaran hukum, ketertiban masyarakat dan pelanggaran ketertiban umum.

2. Peradilan masih tetap diharapkan berperan sebagai the last resort yakni sebagai tempat terakhir mencapai kebenaran dan keadilan sehingga pengadilan masih diandalkan sebagai badan yang berfungsi menegakkan kebenaran dan keadilan (to enforce the truth and justice).

Sistem peradilan pada hakikatnya identik dengan system penegakan hukum, karena proses peradilan pada hakikatnya suatu proses menegakkan hukum. Jadi pada hakikatnyanya identik dengan "sistem kekuasaan kehakiman" karena "kekuasaan kehakiman" pada dasarnya merupakan "kekuasan/ kewenangan menegakkan hukum. Apabila difokuskan dalam bidang hokum pidana, dapatlah dikatakan bahwa "sistem peradilan Pidana" pada hakikatnya merupakan 'sistem penegakan hukum pidana" yang pada hakikatnya juga identik dengan "sistem kuasaan kehakiman di bidang hukum pidana". Sistem peradilan dilihat secara integral merupakan satu kesatuan berbagai sub-sistem (komponen) yang terdiri dari komponen "substansi hukum, sruktur hukum dan budaya hukum ${ }^{12}$. Substansi hukum berkenaaan dengan isi/materi hukum. Struktur hukum menyangkut badan/lembaga yang menanganai penegakan hukum. Budaya hukum berkaitan dengan pendapat dan respon masyarakat terhadap hukum. Ketiga komponen ini saling berkaitan dalam menentukan berjalannya sistem hukum.

Menurut Muladi, sistem peradilan pidana merupakan jaringan (network) peradilan yang menggunakan hukum pidana sebagai sarana utamanya, baik hukum pidana materiil, hukum pidana formil maupun hukum pelaksanaan pidana ${ }^{13}$. Peradilan merupakan tempat untuk memperoleh keadilan termasuk bagi penyalahguna narkotika.

Penyalahgunaan narkotika telah dikualifikasikan sebagai tindak pidana yang awalnya diatur dalam Undang-undang Nomor 22 tahun 1997. Berbeda dengan Undang-undang Nomor 22 Tahun 1997, terdapat ketentuan-ketentuan baru khususnya tentang penyalahguna narkotika dalam Undangundang Nomor 35 Tahun 2009. Pasal 1 Undang-undang Nomor 35 Tahun 2009 disebutkan penyalahguna adalah orang yang menggunakan narkotika tanpa hak atau melawan hukum ${ }^{14}$. Dengan adanya pengertian ini maka subjek hukum berupa badan hukum/koorporasi tidak mungkin dikualifikasikan sebagai penyalahguna narkotika.

Penyalah guna narkotika dimungkinkan berstatus sebagai pecandu narkotika atau korban

\footnotetext{
${ }^{10}$ Barda Nawawi Arief, Perkembangan Sistem Pemidanaan Di Indonesia, Pustaka Magister, Semarang, 2017,hlm 54

${ }^{11}$ M. Yahya Harahap, 1997,Beberapa Tinjauan Mengenai Sistem peradilan dan Penyelesaian Sengketa, Citra Aditya Bakti, Bandung, hal. 237

${ }^{12}$ Barda Nawawi Arief,, Reformasi Sistem Peradilan Hukum di Indonesia, Badan Penerbit Universitas Diponegoro, Semarang,2007, hal. 3.

${ }^{13}$ Muladi,, Kapita Selekta Sistem Peradilan Pidana, Badan Penerbit Universitas Diponegoro, Semarang,1995, hal 4.

${ }^{14}$ Undang-undang Nomor 35 Tahun 2009 tentang Narkotika, Pasal 1 angka 15
} 
penyalahgunaan narkotika. Hal ini diatur dalam Pasal 127 ayat (2) dan (3) yang mewajibkan Hakim dalam memutus perkara penyalahguna narkotika untuk memperhatkan apakah penyalah guna termasuk pecandu atau korban penyalahgunaan narkotika. Adapun yang dimaksud dengan Pecandu Narkotika adalah orang yang menggunakan atau menyalahgunakan narkotika dan dalam keadaan ketergantungan pada narkotika, baik secara fisik maupun psikis. Sedangkan Korban Penyalahgunaan Narkotika adalah seseorang yang tidak sengaja menggunakan narkotika karena dibujuk, diperdaya,ditipu,dipaksa dan/atau diancam untuk menggunakan Narkotika.

Undang-undang Nomor 35 Tahun 2009 juga memuat larangan penyalahgunaan narkotika secara tanpa hak juga diatur dalam undang-undang ini sebagaiman tercantum dalam Pasal 127 ayat (1) sebagai berikut : "setiap penyalahguna : a) narkotika golongan I bagi diri sendiri dipidana dengan pidana penjara paling lama 4 tahun; b) narkotika golongan II bagi diri sendiri dipidana paling lama 2 (dua) tahun; dan c) narkotika golongan narkotika golongan III bagi diri sendiri dipidana dengan pidana penjara paing lama 1 (satu) tahun ${ }^{15 \prime \prime}$.

Dalam undang-undang ini, diatur setiap penanganan perkara penyalah gunaan narkotika, hakim dalam memutus perkara wajib memperhatikan ketentuan sebagaimana dimaksud dalam Pasal 54 , Pasal 55 dan Pasal $103^{16}$. Pasal 54 menyebutkan "pecandu narkotika dan korban penyalahgunaan narkotika wajib menjalani rehabilitasi medis dan rehabilitasi sosial"17. Ketentuan dalam Pasal 55 mengatur orang tua atau wali pecandu narkotika yang masih dibawah umur wajib melaporkan kepada pusat kesehatan masyarakat, rumah sakit, dan/atau lembaga rehabilitasi sosial yang ditunjuk oleh Pemerintah untuk mendapatkan pengobatan dan/atau perawatan melalui rehabilitasi medis dan rehabilitasi sosial. Sedangkan untuk pecandu narkotika yang sudah cukup umur wajib melaporkan diri atau dilaporkan oleh keluarganya ke pusat kesehatan masyarakat, rumah sakit, dan/atau lembaga rehabilitasi sosial yang ditunjuk oleh Pemerintah untuk mendapatkan pengobatan dan/atau perawatan melalui rehabilitasi medis dan rehabilitasi sosial. Apabila orang tua/wali pecandu narkotika atau pecandu narkotika yang sudah cukup umur melapor dengan sukarela maka proses pidana akan dikesampingkan.

Adapun ketentuan Pasal 103 mengatur hakim yang memeriksa perkara pecandu narkotika dapat : memutus untuk memerintahkan yang bersangkutan menjalani pengobatan dan/atau perawatan melalui rehabilitasi jika pecandu narkotika terbukti bersalah melakukan tindak pidana narkotika atau menetapkan untuk memerintahkan yang bersangkutan menjalani pengobatan dan/atau perawatan melalui rehabilitasi jika pecandu narkotika tersebut tidak terbukti bersalah melakukan tindak pidana narkotika. Masa menjalani pengobatan dan/atau perawatan bagi pecandu narkotika diperhitungkan sebagai masa menjalani hukuman ${ }^{18}$.

Apabila dicermati maka dalam undang-undang Nomor 35 Tahun 2009 ini, sistem pemidanaan terhadap penyalah guna narkotika selain penerapan pidana penjara juga memungkinkan hakim untuk menerapkan tindakan kepada penyalahguna narkotika berupa tindakan untuk menjalani perawatan

\footnotetext{
15 Ibid, Pasal 127 ayat (1)

${ }^{16}$ Ibid, Pasal 127 ayat (2)

17 Ibid, Pasal 54

18 Ibid, Pasal 103
} 
rehabilitasi medis dan sosial. Hal ini merupakan kemajuan yang sangat berarti mengingat penyalah guna narkotika hakekatnya juga sebagai korban dari penyalahgunaan narkotika.

Penerapan pidana penjara bagi penyalahguna khususnya pecandu narkotika tidak akan mampu menyelesaikan akar persoalan apabila pelaku tidak diberikan perawatan sehingga mampu untuk melepaskan diri dari ketergantungan terhadap narkotika. Pecandu narkotika memerlukan treatment khusus baik secara medis maupun sosial agar yang bersangkutan dapat kembali ke dalam masyarakat secara normal.

Penerapan tindakan rehabilitasi bagi pecandu narkotika mencerminkan pendekatan humanistic dalam penegakan hukum terhadap penyalahguna narkotika. Undang-undang ini menghendaki Hakim untuk dengan seksama mempertimbangkan keadaan dan kepentingan pelaku. Sanksi hukum tidak serta merta dijadikan sebagai alat pembalasan tapi juga harus mampu mengembalikan pelaku ke dalam masyarakat, dengan kata kata lain undang-undang ini juga berorientasi pada perlindungan kepentingan pelaku.

Ketentuan tentang rehabilitasi tersebut juga mencerminkan prinsip individualisasi pidana. Prinsip individualisasi pidana menurut Sudarto adalah dalam memberikan sanksi pidana selalu memperhatikan sifat-sifat dan keadaan-keadaan si pembuat ${ }^{19}$. Prinsip ini bertolak dari kepentingan individu pelaku tindak pidana dalam sistem hukum pidana. Prinsip ini juga merupakan salah satu ciri dari aliran hukum modern yang berorientasi tidak hanya pada perbuatan tapi juga pada manusia/pelaku. Pendekatan ini juga disebut sebagai pendekatan mono-dualistik, dalam arti memperhatikan keseimbangan dan kepentingan antara kepentingan masyarakat dan individu ${ }^{20}$.

Menurut Barda Nawawi Arief, beberapa karakteristik prinsip individualisasi pidana sebagai berikut :

1. Pertanggungjawaban (pidana) bersifat pribadi/perorangan (asas persona);

2. Pidana hanya diberikan kepada orang yang bersalah (asas culpabilitas:"tiada pidana tanpa kesalahan");

3. Pidana harus disesuaikan dengan karakteristik dan kondisi si pelaku; ini berarti harus ada kelonggaran/ fleksibilitas bagi hakim dalam memilih sanksi pidana (jenis maupun berat ringannya sanksi) dan harus ada kemungkinan modifikasi pidana (perubahan/penyesuain) dalam pelaksanaannya ${ }^{21}$.

Merujuk pendapat dari Barda Nawai Arief diatas, maka ketentuan dalam Pasal 54 dan 103 undangundnag Nomor 35 Tahun 2009 menghendaki pidana terhadap penyalahguna narkotika harus disesuaikan dengan karakteristik dan kondisi pelaku. Para penyalahguna narkotika harus melalui serangakain pemeriksaan untuk menentukan apakah yang bersangkutan sebagai pecandu atau korban penyalahguna narkotika. Dengan demikian nantinya pidana yang dterapkan sesuai dengan kebutuhan pelaku. Pendekatan dari sisi individu pelaku selaras dengan pendapat Sudarto yang mengemukakan :"kalau membicarakan pidana, maka harus membicarakan orang yang melakukan

\footnotetext{
${ }^{19}$ Sudarto, Kapita Selekta Hukum Pidana, Alumni, Bandung, 1981,hlm.80

${ }^{20}$ Sri Endah Wahyuningsih, Op.Cit. hlm.88

${ }^{21}$ Barda Nawawi Arief, Bunga Rampai Kebijakan Hukum Pidana (Perkembangan Penyusunan Konsep KUHP Baru),Kencana Prenada Media Grup, Jakarta, 2008,hlm. 83
} 
kejahatan. Orang ini adalah seperti kita semua, tidak berbeda sedikitpun, kecuali bahwaia telah melakukan perbuatan yang dilarang dan dinyatakan bersalah oleh hakim. Jadi pembaharuan hukum pidana tetap berkisar kepada manusia sehingga ia tidak boleh sekali-kali meninggalkan nilai-nilai kemanusiaan, ialah kasih sayang terhadap manusia"22.

Pecandu narkotika baik secara fisik maupun psikhis membutuhkan pertolongan medis dan social. Terapi yang digunakan untuk mengentaskan mereka dari kecanduan tidak dapat dilakukan dengan cara pemberian sanksi pidana penjara saja. Penerapan pidana penjara bagi pecandu tidak mmapu menyembuhkan ketergantungannya dari narkotika. Apalah artinya jika pecandu narkotika dipenjara tanpa diikuti dengan tindakan pengobatan, tentunya ketika pecandu ini keluar dari penjara dia akan tetap menjadi seorang pecandu. Pecandu narkotika memerlukan bantuan medis untuk menyembuhkan ketergantungannya. Undang-undang Nomor 35 Tahun 2009 telah mengakomodir perlindungan terhadap para penyalahguna narkotika yang termasuk pecandu narkotika dan korban penyalahguna narkotika berupa dibukanya penerapan tindakan berupa rehabilitasi medis dan sosial, hal ini tentunya mengubah paradigma tujuan pemidanaan terhadap penyalahguna narkotika.

Pemidanaan tidak hanya berangkat pada pemikiran pembalasan kepada pelaku kejahatan atau pencegahan supaya melindungi masyarakat tetapi telah meluas hingga kepada suatu sistem pidana yang terpadu yang menyatukan berbagai sendi penegak hukum dalam melaksanakan sistem tersebut sesuai dengan yang dicita-citakan. Tanggung jawab sistem pidana sudah harus dimulai sejak dilakukannya pencegahan sejak dilakukannya kejahatan, terciptanya kejahatan oleh pelaku kejahatan, dan tahapan-tahapan lainnya hingga kepada berintegrasinya kembali pelaku kejahatan sebagai manusia yang seutuhnya di dalam masyarakat serta kuatnya penegak hukum di dalamnya ${ }^{23}$.

Pemidanaan selayaknya tidak hanya berorientasi pada pembalasan tapi juga harus berorientasi kepada kepentingan individu (pelaku kejahatan) dan kepentingan masyarakat. Dalam perkembangan hukum pidana juga dikenal beberapa teori pemidanaan sebagai berikut :

a. Teori absolut (teori retributif)

Teori ini memandang bahwa pemidanaan merupakan pembalasan atas kesalahan yang telah dilakukan, jadi berorientasi pada perbuatan dan terletak pada kejahatan itu sendiri. Pemidanaan diberikan karena si pelaku harus menerima sanksi itu demi kesalahannya. Menurut teori ini, dasar hukuman harus dicari dari kejahatan itu sendiri, karena kejahatan itu telah menimbulkan penderitaan bagi orang lain, sebagai imbalannya (vergelding) si pelaku harus diberi penderitaan ${ }^{24}$. Setiap kejahatan wajib diikuti dengan pidana. Menurut Hegel bahwa, pidana merupakan keharusan logis sebagai konsekuensi dari adanya kejahatan ${ }^{25}$. Seseorang mendapat pidana oleh karena melakukan kejahatan tanpa mempertimbangkan akibat apa yang ditimbulkan dan apakah masyarakat dirugikan. Pembalasan sebagai alasan untuk memidana suatu kejahatan ${ }^{26}$. Penjatuhan

\footnotetext{
${ }^{22}$ Sudarto dalam Sri Endah Wahyuningsih, Op.Cit hlm 84

${ }^{23}$ Yunaldi, Pelaksanaan Diversi Terhadap Anak Pelaku Tindak Pidana Lalu Lintas Pada Tingkat Penyidikan, tesis, Magister (S2) Ilmu Hukum, Universitas Islam Sultan Agung Semarang, 2016, hal. 5.

${ }^{24}$ Leden Marpaung, Asas Teori Praktek Hukum Pidana, Sinar Grafika, Jakarta,2009, hal. 105

${ }^{25}$ Muladi dan Barda Nawawi Arief, Bunga Rampai Hukum Pidana, Alumni, Bandung, 1992, hal. 12

${ }^{26}$ Dwija Priyanto, Sistem Pelaksanaan Pidana Penjara Di Indonesia, PT. Rafika Aditama, Bandung,2009, hlm. 24
} 
pidana pada dasarnya penderitaan pada penjahat dibenarkan karena penjahat telah membuat penderitaan bagi orang lain ${ }^{27}$. Tujuan pemidanaan tidak untuk memperbaiki, mendidik atau memasyarakatkan kembali pelaku.

b. Teori relatif (deterrence)

Teori ini memandang pemidanaan bukan sebagai pembalasan atas kesalahan si pelaku, tetapi sebagai sarana mencapai tujuan bermanfaat untuk melindungi masyarakat menuju kesejahteraan. Dalam teori ini, tujuan pemidanaan sebagai sarana pencegahan, yaitu pencegahan umum yang ditujukan pada masyarakat. Hukuman yang dijatuhkan untuk melaksanakan maksud atau tujuan dari hukuman itu, yakni memperbaiki ketidakpuasan masyarakat sebagai akibat kejahatan itu. Tujuan hukuman harus dipandang secara ideal, selain dari itu, tujuan hukuman adalah untuk mencegah (prevensi) kejahatan ${ }^{28}$. Dengan kata lain pemidanaan bertujuan mencegah dan mengurangi kejahatan. Pidana harus dimaksudkan untuk mengubah tingkah laku orang yang melakukan kejahatan dan orang lain yang berpotensi melakukan kejahatan. Pidana dijatuhkan bukan karena orang membuat kejahatan, melainkan agar orang tersebut tidak melakukan kejahatan. Teori ini sering juga disebut teori tujuan (utilitarian theory) ${ }^{29}$.

c. Teori gabungan (integratif)

Teori ini mendasarkan pidana pada asas pembalasan dan asas tertib pertahanan tata tertib masyarakat, dengan kata lain dua alasan itu menjadi dasar dari penjatuhan pidana. Pada dasarnya teori gabungan adalah gabungan teori absolut dan teori relatif. Gabungan kedua teori itu mengajarkan bahwa penjatuhan hukuman adalah untuk mempertahankan tata tertib hukum dalam masyarakat dan memperbaiki pribadi si penjahat ${ }^{30}$. Teori gabungan ini dapat dibedakan menjadi dua golongan besar, yaitu ${ }^{31}$ :

1) Teori gabungan yang mengutamakan pembalasan, tetapi pembalasan itu tidak boleh melampaui batas dari apa yang perlu dan cukup untuk dapatnya dipertahankannya tata tertib masyarakat;

2) Teori gabungan yang mengutamakan perlindungan tata tertib masyarakat, tetapi penderitaan atas dijatuhinya pidana tidak boleh lebih berat daripada perbuatan yang dilakukan terpidana.

d. Teori treatment

Teori ini mengemukakan bahwa pemidanaan sangat pantas diarahkan kepada pelaku kejahatan, bukan kepada perbuatannya. Teori ini memiliki keistimewaan dari segi proses resosialisasi pelaku sehingga diharapkan mampu memulihkan kualitas sosial dan moral masyarakat agar dapat berintegrasi lagi ke dalam masyarakat. Aliran ini beranggapan bahwa manusia tidak memiliki kehendak yang bebas, perilakunya dipengaruhi oleh nilai-nilai dan kondisi sosial lingkungannya. Oleh karena itu, sanksi yang diberikan harus bersifat mendidik, dalam hal ini

\footnotetext{
27 Teguh Prasetyo dan Abdul Halim Barkatullah,Politik Hukum Pidana (Kajian kebijakan Kriminalisasi dan Dekriminalisasi), Pustaka Pelajar, Jakarta, 2005,hlml. 90

${ }^{28}$ Leden Marpaung, Op.Cit., hal 106

${ }^{29}$ Dwija Priyanto, Op.Cit., hal 26

${ }^{30}$ Leden Marpaung, Op.Cit, hal 107

${ }^{31}$ Adami Chazawi, Pelajaran Hukum Pidana Bagian 1 Stelsel Pidana, Tindak Pidana, Teori-Teori Pemidanaan, dan Batas Berlakunya Hukum Pidana,PT Raja Grafindo Persada, Jakarta, 2012, hlm. 106
} 
seorang pelaku kejahatan membutuhkan sanksi yang bersifat treatment ${ }^{32}$. Treatment ini berupa perawatan untuk merekonsiliasi pelaku kejahatan agar menjadi manusia yang baik.

e. Teori perlindungan sosial (social defence)

Teori ini merupakan perkembangan lebih lanjut dari aliran modern dengan tokoh terkenalnya Filippo Gramatica, tujuan utama dari teori ini adalah mengintegrasikan individu ke dalam tertib sosial dan bukan pemidanaan terhadap perbuatannya. Hukum perlindungan sosial mensyaratkan penghapusan pertanggungjawaban pidana (kesalahan) digantikan tempatnya oleh pandangan tentang perbuatan anti sosial, yaitu adanya seperangkat peraturan-peraturan yang tidak hanya sesuai dengan kebutuhan untuk kehidupan bersama tapi sesuai dengan aspirasiaspirasi masyarakat pada umumnya ${ }^{33}$.

Merujuk teori-teori diatas maka tujuan pemidanaan terhadap penyalahguna narkotika sebagaimana dalam Undang-undang Nomor 35 Tahun 2009 tidak semata-mata untuk memberikan efek jera bagi pelaku maupun mencegah orang lain untuk melakukan perbuatan yang sama namun juga mengupayakan agar pelaku memperoleh perawatan sehingga dapat kembali ke masyarakat dalam keadaan yang baik. Tentunya pelaku dengan keadaan yang sudah terbebas dari kergantungan narkotika dengan sendirinya akan menghindarkan pelaku kembali terjerumus dalam perbuatan yang sama. Hal ini tentu saja juga berdampak pada kembalinya keadaan sosial yang sempat tercabik oleh perbuatan pelaku dan secara tidak langsung menghadirkan kedamaian di lingkungannya.

Teori-teori tersebut,tidak ada yang lebih tepat untuk menggambarkan tujuan pemidanaan yang ideal di Indonesia. Falsafah yang dianut di Indonesia adalah Pancasila maka seharusya pemidanaan yang diterapkan harus berlandasan pancasila. Menurut M. Sholehuddin falsafah Indonesia adalah Pancasila yang menuntut keseimbangan dalam keselarasan antara kepentingan individu, masyarakat dan negara. Tanggungjawab pemidanaan tidak dapat dibedakan serta merta kepada pelaku kejahatan karena pada dasarnya kejahatan itu sendiri tidak dapat dilepaskan dari realitas kehidupan suatu masyarakat. Menurut paham ini, pemidanan atau hukum pidana di Indonesia harus berorientasi kepada kepentingan individu (pelaku kejahatan) dan kepentingan masyarakat termasuk korban kejahatan ${ }^{34}$. Sistem pemidanaan juga diharapkan tetap menjunjung tinggi harkat dan martabat manusia, berorientasi pada perbaikan diri pelaku dan sarana pencegahan kejahatan

Pembaharuan tujuan pemidanaan dalam penegakan hukum di Indonsia mendesak untuk dilakukan namun sayangnya sampai dengan sekarang Rancangan Kitab Undang-undang Hukum Pidana belum juga disahkan padahal dalam Rancangan KUHP tersebut telah memuat konsep tujuan dan pedoman pemidanaan yang berlandaskan nilai keseimbangan antara kepentingan pelaku dan masyarakat. Pedoman menerapkan perumusan pidana diatur dalam Pasal 58-59 RUU KUHP (Konsep 2005-2008). Dengan adanya pedoman ini, dimungkinkan hakim menjatuhkan jenis pidana/sanksi lain yang tidak tercantum dalam perumusan delik yang hanya diancam dengan pidana tunggal atau bahkan dapat menjatuhkan pidana/sanksi lain itu bersama-sama dengan jenis pidana yang dirumuskan secara

\footnotetext{
${ }^{32}$ Teguh Prasetyo dan Abdul Halim Barkatullah, Op.Cit.,Hal.96-97

${ }^{33}$ Muladi dan Barda Nawawi Arief, Op.Cit, hal 12

${ }^{34}$ Marlina, Hukum Penitensier, Refika Aditama, Bandung, 2011, hal. 35
} 
tunggal $^{35}$. Dengan kata lain, penjatuhan pidana dapat digabungkan antara pidana dan tindakan (kumulatif) atau memilih antara pidana atau tindakan (alternative). Hal ini merupakan penerapan dari ide elastisitas ${ }^{36}$.

Pendekatan prinsip individualisasi pidana yang menitikberatkan pada "manusia" dalam perkembangaan hukum pidana semakin hari semakin mendalam ${ }^{37}$. Oleh karena itu sangat relevan jika dalam pembaharuan hukum pidana nasional berorientasi pada ide individualisasi piadan sebagai konseskuensi pentingnya pendekatan kemanusiaan dalam setiap langkah kebijakan pembangunan nasional yang berlandaskan falsafah Pancasila tertutama sila kemanusiaan yang adil dan beradab ${ }^{38}$.

Dalam upaya penegakan hukum, menurut Gustav Radbruch ${ }^{39}$ terdapat 3 (tiga) nilai dasar yang harus diwujudkan dan perlu mendapat perhatian serius dari para pelaksana hukum yakni nilai keadilan, nilai kepastian hukum dan kemanfaatan. Terutama nilai dasar kemanfaatan ini akan mengarahkan hukum pada pertimbangan kebutuhan masyarakat pada suatu saat tertentu, sehingga hukum itu benar-benar mempunyai peranan yang nyata bagi masyarakat. ${ }^{40}$ Pendekatan prinsip individualisasi pidana dalam penanganan perkara penyalahgunaan narkotika tidak hanya mengutamakan kepastian hukum tapi juga memberi manfaat kepada pelaku dan masyarakat.

\section{PENUTUP}

Sistem pemidanaan terhadap pelaku tindak pidana narkotika sebagaimana ditur dalam Undangundang Nomor 35 Tahun 2009 tentang narkotika tidak hanya mengedepankan pemberian pidana tetapi terbuka kemungkinan diterapkannya tindakan berupa rehabilitasi medis dan social dengan tujuan membebaskan pelaku dari ketergantungan narkotika. Hal ini mencerminkan pendekatan humanistic yang memperhatikan sisi-sisi keadaan pelaku yang pada hakekatnya penyalahguna narkotika juga sebagai korban peredaran gelap narkotika. Tentunya pelaku dengan keadaan yang sudah terbebas dari kergantungan narkotika dengan sendirinya akan menghindarkan pelaku kembali terjerumus dalam perbuatan yang sama. Hal ini tentu saja juga berdampak pada kembalinya keadaan sosial yang sempat tercabik oleh perbuatan pelaku dan secara tidak langsung menghadirkan kedamaian di masyarakat.

Penerapan tindakan rehabilitasi bagi penyalahguna narkotika dalam sistem pemidanaan juga memcerminkan perlindungan harkat dan martabat manusia serta berorientasi pada perbaikan diri pelaku dan sarana pencegahan kejahatan.

\footnotetext{
${ }^{35}$ Barda Nawawi Arief, Tujuan \& Pedoman pemidanaan(Perpekstif pembaharuan \& perbandingan Hukum Pidana), Pustaka Magister, semarang 2017,hlm 65.

${ }^{36} \mathrm{Ibid}, \mathrm{hlm} 67$

${ }^{37}$ Roeslan saleh, mengadili Adalah Proses Yang terjadi Antar Manusia dan Manusia, Aksara Baru, Jakarta, 1993 ,hlm 11.

${ }^{38}$ Sri Endah Wahyuningsih, Op.Cit hlm 85.

${ }^{39}$ Gustav Radbruch, 1961,Einfuhrung in die Rechtswissenschaft,Stutgart:K.F.Kohler, dalam Satjipto Raharjo, IImu Hukum,Alumni, Bandung, hal.19-21

${ }^{40}$ Esmi Warassih, 2015,Pranata Hukum,Sebuah Telaah Sosiologis, Pustakan Magister,Semarang,hal.11.
} 


\section{Daftar Pustaka}

A. Buku-buku :

Adami Chazawi, Pelajaran Hukum Pidana Bagian 1 Stelsel Pidana, Tindak Pidana, Teori-Teori Pemidanaan, dan Batas Berlakunya Hukum Pidana,PT Raja Grafindo Persada, Jakarta, 2012.

Barda Nawawi Arief, Perkembangan Sistem Pemidanaan Di Indonesia, Pustaka Magister,Semarang, 2017

----------, Tujuan \& Pedoman pemidanaan(Perpekstif pembaharuan \& perbandingan Hukum Pidana), Pustaka Magister, Semarang, 2017

----------, Bunga Rampai Kebijakan Hukum Pidana (Perkembangan Penyusunan Konsep KUHP Baru),Kencana Prenada Media Grup, Jakarta, 2008

--------- , Reformasi Sistem Peradilan Hukum di Indonesia, Badan Penerbit Universitas Diponegoro , Semarang, 2007

Dwidja Priyanto, Sistem Pelaksanaan Pidana Penjara Di Indonesia, Bandung, PT. Rafika Aditama, 2009.

Herlina Martono dan Satya Joewana, Belajar Hidup Bertanggungjawab, Menangkal Narkotika dan Kekerasan, Balai Pustaka, Jakarta, 2008

Kusno Adi,Diversi Sebagai Upaya Alternatif Penanggulangan Tindak Pidana Narkotika oleh Anak, UMM Press, Malang,2009

Leden Marpaung, Asas-Teori-Praktek Hukum Pidana, Jakarta : Sinar Grafika, 2009.

Marlina,Hukum Penitensier, Refika Aditama, Bandung, 2011.

Muladi dan Barda Nawawi, Bunga Rampai Hukum Pidana, Bandung : Alumni, Bandung, 1992.

Kapita Selekta Sistem Peradilan Pidana, Badan Penerbit Universitas Diponegoro, Semarang, 1995

M. Yahya Harahap, 1997,Beberapa Tinjauan Mengenai Sistem peradilan dan Penyelesaian Sengketa, Citra Aditya Bakti, Bandung

Roeslan saleh, Mengadili Adalah Proses Yang terjadi Antar Manusia dan Manusia, Aksara Baru, Jakarta, 1993.

Satjipto Raharjo, Ilmu Hukum, PT.Citra Aditya Bakti, Bandung, 1996

Sudarto, Hukum Pidana 1, Semarang, Yayasan Sudarto d/a Fakultas Hukum Undip, Semarang, 1990.

Sukarmi, Psikologi Hukum, Unissula Press, Semarang,2012

Teguh Prasetyo dan Abdul Halim Barkatullah, Politik Hukum Pidana (Kajian Kebijakan Kriminalisasi dan Dekriminalisasi), Jakarta : Pustaka Pelajar, 2005

B. Jurnal Hukum :

Yunaldi, Pelaksanaan Diversi Terhadap Anak Pelaku Tindak Pidana Lalu Lintas Pada Tingkat Penyidikan, tesis, Magister (S2) Ilmu Hukum, Universitas Islam Sultan Agung Semarang, 2016.

C. Perundang-undangan :

Undang - Undang Dasar Tahun 1945. 
Undang-undang Nomor 22 Tahun 1997 Tentang Narkotika.

Undang-undang Nomor 35 Tahun 2009 Tentang Narkotika.

Rancangan Kitab Undang-undang Hukum Pidana Konsep 2005-2008

D. Lain-lain

https://media.neliti.com//media/publications/169828-10-faktor-faktor -penyebab-penyalahgunaanna.pdf diakses hari Senin tanggal 6 Nopember 2017 jam 11.00 WIB

www.republika.co.id/berita/koran/dialog-jumat/15/05/08/no0x0828-narkotika-dalam-fikih-Islam diakses pada hari Rabu tanggal 07 Nopember 2017 jam 10.00 WIB 